\title{
Evlat Edinilen Çocuklarda Bağlanma
}

\author{
Attachment in Adopted Children
}

\begin{abstract}
Kızbes Meral KILIÇ*
Öz: Evlat edinme süreci, evlat edinen ebeveynlerin ve evlat edinilen çocukların hayatlarında birçok ödül ve zorlukla ilişkilidir. Bağlanma, kişileri birbirine bağlayan güçlü bir sevgi ve insanların tehdit altındayken duygusal sıkıntılarını düzenledikleri ve başkalarına yakınlık arayarak güvenlik sağladıkları davranışsal bir sistemdir. Erken dönemde meydana gelen bağlanma ilişkisi kişilerin davranışlarını ve daha sonraki dönemlerde yaşanılacak ilişkilerin niteliğini önemli derecede etkilemektedir. İdeal olan, çocukların biyolojik anne babaları tarafından büyütülmesidir, ancak annenin hastalığı, anne babanın ölümü, maddi imkânsızlıklar, anne babanın boşanması, savaşlar, bebeğin meşru olmayan yollarla dünyaya gelmesi, evlat edinenlerin çeşitli nedenlerle çocuklarının olamaması, doğum yapma korkusu, çocuk yapmama tercihini kullanma, çocuğu olup bakıma muhtaç çocuk/ları evlat edinmek isteme gibi birçok nedenle bazı çocuklar evlat edinilmektedir. Evlat edinen ebeveynlerle evlat edinilen çocuklar arasındaki bağlanma ilişkisi onların davranışlarının, ilişkilerinin ve psikolojik durumlarının kalitesini de belirleyen bir faktördür. Bu çalışmada, bağlanmanın tanımı, bağlanma türleri, bağlanmayı etkileyen faktörler, evlat edinme ve evlat edinme sürecinde bağlanma süreci ele alınmış ve tartışılmıştır.
\end{abstract}

Anahtar sözcükler: Bağlanma, Evlat edinme, Çocuk, Ebeveyn

Abstract: The adoption process is associated with many rewards and difficulties in the lives of adoptive parents and adopted children. Attachment is a strong love that connects people and a behavioral system in which people are exposed to emotional distress when threatened and provide security by seeking closeness to others. The early bonding relationship has a significant effect on the behavior of individuals and the nature of the relationships to be experienced in later periods. Ideally, children should be raised by their biological parents, but the mother's illness, the death of the parents, financial difficulties, the divorce of parents, wars, the birth of the baby by unlawful means, the inability of the adopters to have children for various reasons, the fear of giving birth, the choice of not having children, some children are adopted for many reasons, such as, having a child and also wanting to adopt children in need of care. The bond of attachment between the adoptive parents and the adopted children is also a factor in the quality of their behavior, relationships, and psychological state. In this study, the definition of attachment, the types of attachment, the factors affecting attachment, the attachment process in the adoption and adoption process are discussed.

Keywords: Attachment, Adoption, Child, Parent

\section{Giriş}

Çocukların biyolojik anne babaları dışındaki insanlar tarafından benimsenerek evlat edinilmesi insanlık tarihinin tüm dönemlerinde ve bütün kültürlerde görülmektedir (Palacios \& Brodzinsky 2010, 270). Evlat edinme süreci, evlat edinen ve evlat edinilenlerin hayatındaki birçok ödül ve

\footnotetext{
* Dr. Öğr. Ü., Akdeniz Üniversitesi, Kumluca Sağllk Bilimleri Fakültesi, Çocuk Gelişimi Bölümü, Antalya. kmeralkilic@akdeniz.edu.tr , https://orcid.org/0000-0002-4209-2615
} 
zorluklarla ilişkilidir. Evlat edinme sayesinde, biyolojik ebeveynleri tarafından yetiştirilemeyen çocuklar için düzenli ve sevgi dolu bakım, güvenlik ve ömür boyu aile ilişkileri oluşturulmaya çalıştırılır. Evlat edinenler için ebeveyn olma sevincini yaşama, bakıma muhtaç çocukların gelişimini sağlama ve çoğu durumda, çocukların erken dönem olumsuz deneyimlerinin etkilerini iyileştirme gibi durumlar meydana gelir (Brodzinsky 2011, 200). Bazı çalışmalarda, evlat edinilenlerin evlat edinilmeyenlere göre daha fazla benlik saygisı, depresyon ve kayg1 problemleri yaşadıkları belirtilmişken (Friedlander 1999; Levy-Shiff 2001; Tieman et al. 2005), bazı çalışmalarda herhangi bir sorun yaşamadıkları (Brodzinsky 1993; Juffer \& van IJzendoorn 2007) bildirilmiştir. Son zamanlarda yapılmış olan meta-analiz çalışmalarında evlat edinilmiş çocukların davranışsal problemlerinin daha fazla olduğu ancak, uyum problemleri yaşamadıkları bildirilmektedir (Juffer \& van IJzendoorn 2005; Nickman et al. 2005; van IJzendoorn et al. 2005 akt. Feeney et al. 2007).

Bağlanma, çocuğun birincil bakıcılarına karşı geliştirdiği bağlılık ilişkisini tanımlamada kullanılan, yaşamın ilk yılının ikinci yarısında gözlemlenebilen ve aşamalı olarak gelişen bir süreçtir (Pearce 2009, 13). Bağlanma teorisi, her gelişim döneminde gerçekleşen uyumun, önceki dönemdeki işleyişi temel aldığını ve dönüştürdügünü savunur. Bağlanma teorisine göre çocuğun çevre ile sonraki işlemlerine temel oluşturduğu için erken dönemdeki yaşam ve deneyimlerin özel bir önemi vardır. Bebeklik ve çocukluk döneminde en yakın ilişkilerde duygusal yakınlık deneyimlerine dayanılarak yeni deneyimler yorumlanır ve oluşturulur. Hassas oldukları, bilinçli olarak hatırlanamadıkları ve daha sonraki deneyimlerle daha az kolayca değiştirilebildikleri için bağlanma gibi ilk deneyimler oldukça önemlidir. Bağlanma kalitesindeki erken dönemden itibaren meydana gelen değişiklikler diğer insanlara güven ve kendi kendine değer verme duyguları ve özgüvenin temelini oluşturur (Egeland \& Carlson 2004). Bağlanma, sadece bebeklik dönemini değil, erken çocukluk, geç çocukluk, ergenlik ve erişkinlik dönemlerini de etkilemektedir. Bağlanma; şiddete eğilim (Schimmenti et al. 2014), kendine zarar verme (Wright et al. 2005; Shuk-Ching 2006), madde kötüye kullanımı ve bağımlılığ (Davidson \& Ireland 2009), ihmal ve istismar etme (Morton \& Browne 1998) ya da edilme (Beeghly \& Cicchetti 1994) gibi psikopatolojilerle ilişkili olabilmektedir (Soysal et al. 2005).

İdeal olan, çocukların biyolojik anne babaları tarafından büyütülmesidir, ancak annenin hastalığı, anne babanın ölümü, maddi imkânsızlıklar, anne babanın boşanması, savaşlar, bebeğin meşru olmayan yollarla dünyaya gelmesi, evlat edinenlerin çeşitli nedenlerle çocuklarının olamaması, doğum yapma korkusu, çocuk yapmama tercihini kullanma, çocuğu olup bakıma muhtaç çocuk/ları evlat edinmek isteme gibi birçok nedenle bazı çocuklar evlat edinilmektedir. Evlat edinme süreci, evlat edinen bireyler ile evlat edinilen çocukların hayatlarında çok büyük değişiklikleri beraberinde getirmekte ve bu süreç, her iki tarafın önceki yaşamları, kişilikleri, yaşları, akıl ve fiziksel sağlıkları gibi birçok faktörden etkilenmektedir. Evlat edinen ebeveynlerle evlat edinilen çocuklar arasındaki bağlanma ilişkisi onların davranışlarının, ilişkilerinin ve psikolojik durumlarının kalitesini de belirleyen bir faktördür. Bu çalışmada, evlat edinilen çocuklarda bağlanma başlığı altında, bağlanmanın tanımı, bağlanma türleri, bağlanmayı etkileyen faktörler, evlat edinme ve evlat edinme sürecinde bağlanma süreci ele alınmış ve alanyazındaki araştırmalar çerçevesinde tartışılmıştır.

\section{Bağlanmanın Tanımı}

Bebeklik döneminde gerçekleşen sosyal gelişimin en önemli yanı, bağlanmanın gerçekleşmesidir. Bir çocuk ile özel bir birey arasında gelişen pozitif duygusal bağ (Feldman 2017, 206) olan bağlanma, çocuğun başkalarıyla (ebeveynleriyle veya bakıcılarıyla) anlamlı duygusal ilişkiler kurabilme yetisidir (Budak 2003, 105-106). Bowlby’ye göre bağlanma, kişileri birbirine bağlayan güçlü bir sevgidir. Bağlanma aynı zamanda insanların tehdit altındayken duygusal 
sıkıntılarını düzenledikleri ve başkalarına yakınlık arayarak güvenlik sağladıkları davranışsal bir sistemdir. Çoğumuz için, oluşturduğumuz ilk bağlanma ilişkimiz yaklaşık 6 veya 7 aylıkken ebeveynimizle kurduğumuz ilişkidir (Sigelman \& Rider 2017, 440).

Bowlby’e göre bebeklerde bağlanma ilişkisi kurma eğilimi annelerinin kendilerine bakım vererek ve onları koruyarak hayatta kalmalarına yardımcı olduğu için inşa edilmektedir (Krull 2014, 300). Bowlby bağlanmayı, bebekler ve ebeveynlerin (veya diğer bakım verenlerin) birbirleri ile duygusal bağ kurmalarına yol açan iki yönlü bir süreç olarak tanımlamıştır. Bebekler yetişkinlerin dikkatini cezbeden, şefkat ve ilgi duyma gibi güçlü duyguları ortaya ç1karan sosyal davranışlar -gülümseme, göz teması kurma- sergilerler. Yetişkinler bu davranışlara içtenlikle ve onlarla sosyal temas kurarak karşılık verirler. Böylece bebekler ve onların hayatlarındaki önemli kișiler birbirlerine bağlanırlar (Trawick-Smith 2014, 170). Bağlanma ilișkisi, annelerin baktığı bebeklerde genellikle annedir. Bebekler önce annelerine bağlansalar bile sonra baba, büyük anne, büyük baba, abla ve ağabeylerine de bağl1lık geliştirebilirler. Bu dönem 2-3 yaşa kadar sürer (San-Bayhan \& Artan 2011, 221).

Bağlanma bireylerin yaşamında çok önemli bir ilişkidir. Bebek hayatta kalmak için korunmaya, gözetilmeye ihtiyaç duyar. Bu koruma normalde biyolojik ebeveynleri tarafindan sağlanır, çünkü ebeveynler yavrularının hayatta kalmasını isterler. Evrimsel bakış açısına göre bağlanma ebeveynler için önemlidir çünkü çocuklarıyla genlerini gelecek nesillere taşıyabilirler (van Rosmalen et al. 2014, 11-12). Bağlanma kuramcılarına göre bir kişinin gelecekte sergileyeceği tüm sosyal duygusal davranışlar bebeklik döneminde annesiyle ya da bakım figürüyle kuracağ 1 bağlanma ilişkisi ile şekillenir. Anne ya da baba figürü ve bebek arasındaki olumlu duygular, özellikle korku ve gerginlik anlarında birbirlerine sağladıkları rahatlık ve destek bağlanmayı oluşturur. Bağlanmanın oluşmasında bebeklerin bir takım davranış özellikleri etkili olur. Emme, sokulma, bakış, gülümseme, ağlama bebeğin bağlanma davranışları olup, özellikle ilk aylarda bağlanmada oldukça etkilidir (Küçükturan \& Keleş 2017). Bowlby’e (1969) göre bebekler ayrıca, bağlanma ilişkilerine dayalı içsel çalışma modeli olarak adlandırılan bir tür "zihinsel çerçeve" geliştirmektedir. Bu içsel çalışma modelinin gelecekte kurulacak akran ilişkileri ve romantik ilişkilere temel oluşturduğu düşünülmektedir (akt. Krull 2014, 300).

Bağlanma ilişkisi insanlarda olduğu gibi hayvanlarda da görülmektedir. Harlow, maymunların bağlanma süreçlerini incelemek için bir dizi deney gerçekleştirmiştir. Bu deneylerde maymunlar doğumlarından hemen sonra annelerinden ayrılmış ve yapay anneleriyle büyütülmüşlerdir. Yavru maymunların kafesine biri telden yapılmış ve üzerinde süt şişesi bulunan, diğeri yalnızca yumuşak kumaştan yapılmış ve 1sıtılmış iki "anne" konulmuştur. Araştırmacılar yavru maymunların süt vermeyen ama sıcak ve yumuşak "anne”yi tercih ettiklerini, korktuklarında ona sarıldıklarını görmüşlerdir (Hortaçsu 1997, 50).

Bowlby'e göre bebeğin ebeveynleri ile ilişkisi bebeğin yetişkini yanına çağırmada kullandığ1 doğuştan getirilen bir dizi sinyalle başlar. Zamanla hem yeni bilişsel ve duygusal kapasitenin hem de sıcak ve duyarlı bir bakım geçmişinin yardımı ile gerçek bir duygusal bağ oluşur (Berk 2015, 265). Bağlanma dört aşamada gerçekleşir:

1. Bağlanma Öncesi Aşama (Doğumdan 6 aya kadar): İlk aşama, aralarında ayrım yapmadan insanlara yönelme, bebeğin insan kokusu, insan sesi ve insan yüzünün kaba hatları hakkındaki tercihi ile başlar (van Rosmalen et al. 2014, 13).

2. Bağlanmanın Oluşum Aşaması (6 hafta-6-8 aya kadar): İkinci aşamada, bebeğin ortamındaki belirli insanlara yönelik yönelim, bebeği düzenli olarak gördüğü ve tanıdığı insanlara odaklanmasını sağlar (van Rosmalen et al. 2014, 13). Bebekler bu dönemde birincil bakıc1lar ve diğerleri arasında ayrım yapmaya başlar. Gülüşler tanınmaya dayanır ve bebek bakıcıların yüzünü heyecanla tarar. Bebek bakıcılar odadan çıktıklarında stres belirtileri gösterir ve kısa 
ayrılıkların ardından karşılaştıklarında gülümser (Perace 2009, 21). Bebekler bu aşamada birincil bağlanma figürlerinden ayrıldıklarında protesto tepkisi vermezler (McCartney \& O’Connor 2006).

3. Bağlılık Aşaması (6-8 aydan 18-24 aya kadar): Birincil bağlanmanın aktif olarak geliştiği bu aşamada bebek, çevresini keşfederken motor gelişimi çerçevesinde emekleyebilip yürümeye başlar. Bakıcılarından uzaklaşmaya başladıklarında geri dönerek veya kafasını bakıcıya çevirerek görsel temasa girerek sık sık bakıcılarını kontrol ederler. Bakıcısının yakınında olduğunu bilmek endişe duymadan araştırmasına katkı sağlar. Çocuğun çevresini araştırma esnasında bakıcılarıyla geçici olarak bir araya gelmesi 'duygusal yakıt ikmali’ olarak adlandırılır (Pearce 2009, 21).

4. Karşılıklı İlişki Oluşturma Aşaması (18 ay- 2 yaş ve sonrası): Bu dönemde dil ve temsildeki hızlı gelişmeler, bebeklerin, ebeveynin geliş ve gidişini etkileyen faktörlerin bazılarını anlamalarını ve onların geri döneceğini tahmin etmelerini sağlar. Bu dönemde ayrılığa daha az tepki verirler (Berk 2015, 265).

0-6 yaş döneminin bağlanma için kritik bir dönem olduğu belirtilmektedir. Her şeyden önce, bir çocuğun bağlanma sürecini gerçekleştirememesi neredeyse imkânsızdır. Çocuklar, sıkıntılı ve travmatik yaşam olaylarının ardından bile çabuk toparlanabilme yeteneğine sahiptirler. $\mathrm{Bu}$ nedenle pratikte her zaman bağlanmayı gerçekleştirirler. Kötü muameleye maruz kalmış veya ihmal edilmiş çocuklarda genellikle güvensiz veya düzensiz bağlanma olmasına rağmen bağlanma gözlenmektedir. Otizmli çocukların sosyal engellerine rağmen ebeveynlerine bağlandikları bilinmektedir (van Rosmalen et al. 2014, 16).

Çoğu çocuk birincil bakım veren bakıcılarıyla bağlanma ilişkisi geliştirir ancak, bağlanma ilişkisi her çocukta aynı nitelikte gelişmez. Ainsworth ve arkadaşları bağlanma ilişkilerindeki farkl11ıkları incelemek için “Yabancı Durum Testi”ni geliştirmişlerdir (McCartney \& O'Connor 2006, 95). Bebeklerin kendileriyle ilgilenen, kendilerine bakım sağlayan bakıcılarla (anne, baba, bakıc1, büyükanne/baba) olan bağları, her biriyle olan deneyimlerine dayanarak kendilerini önemseyen diğer insanlarla ilişkilerinin güvenliğinden bağımsız olarak güvenli veya güvensiz olabilir. Örneğin bir bebek, annesine güvenli bir şekilde bağlanırken babasına veya bakıcısına güvenli bir şekilde bağlanmayabilir (Thompson et al. 2003, 101).

Bağlanmanın erken sosyal duygusal gelişim için önemli etkileri bulunmaktadır. Bağlanma ile birlikte çocuklar, sosyal birleşme-ayrılma, duygusal anlayış ve güvenli bağlanma gibi süreçlerle özgüveni geliştiren ilişkileri deneyimler. Bebeğin veya çocuğun kendisine bakım veren her bir bireyle güvenli ilișkiler kurması istendik bir durumdur. Birine güvenli bir șekilde bağlanmak, başkalarıyla kurduğu ilişkileri güvensiz olsa bile sağlıklı psikososyal büyümeyi destekleyebilir (Thompson et al. 2003, 100).

Alanyazın incelendiğinde, bağlanma konusunu Melanie Klein, Otto Kernberg, Heinz Kohut, Nancy Chodorow ve Margeret Mahler gibi kuramciların da ele alıp inceledikleri görülmektedir. "Nesne İlişkileri Teorisyenleri" -örneğin Melanie Klein, Margaret Mahler, Heinz Kohut, Otto Kernberg ve Nancy Chodorow- insan gelişiminde nesnelerin ilişkisel ihtiyaçların amacı olduğunu ve nesne ilişkilerinin erken dönemde ilişkilerin intrapsişik deneyimleri olduğunu belirtirler. Melanie Klein'e göre, nesneler, insanlar olduğu kadar, emzik, oyuncak ayı ve battaniye gibi şeyler de olabilir. Doğumdan itibaren, nesne ilişkileri teorisyenleri, bireylerin insan ilişkileri geliştirmeye ve gelişimlerine yardımcı olabilecek ya da engel olabilecek bağlar oluşturmaya çalıştıklarını öne sürerler (Engler 2013, 158). Margaret Mahler, çocukların kimlik duygusunun, anneleriyle üç aşamalı bir ilişkiye dayandığına inanmıştır. Birincisi, bebeklerin anneleri tarafından bakımı gereken temel ihtiyaçları vardır; sonra, güçlü bir anne ile güvenli bir simbiyotik ilişki geliştirir; ve son olarak, çocuklar annelerinin koruyucu çevresinden çıkıp kimliklerini 
bireyselleştirirler. Heinz Kohut, çocukların ilk bebeklik döneminde ebeveynlerin ve başkalarının kendilerini kişiselleştirilmiş bir kimlik duygusu varmış gibi gördükleri zaman bir benlik duygusu geliştirebildiklerini belirtmektedir (Feist \& Feist 2008, 137). Heinz Kohut'a (1971) göre kendini yatıştırma, güven duyma, bütünlük duygusu sağlama, duygu düzenlenmesi, öz değer duygusunu sürdürebilme gibi benliğin işlevi olan ruhsal düzenlemeleri erken gelişim döneminde bebek için benlik nesnesi olan anne yürütür, yani bebek annenin benliğini kullanmaktadır. Annenin çocuğa yaklaşımı, onunla kurduğu ilişki bebeğin gereksinimlerini doğru algılayan ve uygun tepkiler veren bir empati özelliği taşıyorsa, anne bebeğin benlik duygusunun gelişebilmesi için gerekli deneyimleri sağlayabilir. Annenin empatik yaklaşımı anne bebek için ayna görevi görmektedir. Kohut'un "aynalama” olarak tanımladığı bu işlev bebekteki benlik gelişiminin temelini oluşturur. Annenin aynaladığı özellikler bebek tarafından kendisine uygun şekilde dönüştürülerek içselleştirilir. Kohut'a göre bu içselleştirme sürecinde bebeğin benliği kalıcı bir ruhsal yapı olarak gelişme firsatı bulur. Benlik geliştikçe benlik nesnesinden farklılaşmaya ve ayrışmaya başlar ve zaman içinde çocukta, temelini anneden aldığ 1 , ama onunkinden ayr1 ve özgün bir benlik duygusu gelişir (akt. Çuhadaroğlu-Çetin 2001, 310).

\section{Bağlanmanın Değerlendirilmesi}

Ainsworth ve arkadaşları, anne-çocuk bağlanma ilişkisinde güven derecesini incelemek için "Yabancı Durum" olarak adlandırılan deneysel bir tasarım geliştirmişlerdir. Bu deneyde, anne ve bebeğin iki kez ayrıldığı 8 aşama oluşturularak bebeğin her bir aşamada verdiği tepkiler incelenmiştir. Bu aşamalar sırasıyla;

1. Bebek ve anne, oyuncakları keşfetmek için gözlem odasında kalır.

2. Yabancı kişi odaya girer.

3. Yabancı kişiyle bir süre konuşan anne odadan ayrılır.

4. Yabancı da bir süre sonra odadan ayrılır ve bebek yalnız kalır.

5. Anne bebeği rahatlatmak için geri döner.

6. Anne tekrar ayrilır.

7. Yabancı geri döner ve bebeği rahatlatmaya çalışır.

8. Anne geri döner ve bebeği rahatlatmaya çalışır (Wilmshurst 2009, 54).

Tablo 1'de görüldüğü üzere, Ainsworth ve arkadaşları "Yabancı Durum Testi” sonucu, “Güvenli, Kaygılı/Kaçınan ve Kaygıll Kararsız/Dirençli" olmak üzere üç tür bağlanma ilişkisinin olduğunu belirtmiştir. Main ve Solomon (1990), çalışmaları sonucunda belirtilen bu üç tür bağlanmanın yanısıra "Dağınık/Dezorganize Bağlanma"yı tanımlamışlardır (Levine \& Munsch 2011, 353; Adler-Tapia 2012, 43).

Güvenli Bağlanma: Ainsworth, bebeklerin genellikle anne olan birincil bakıcıyı, yaşamın ilk yılında dünyayı keşfetmek için güvenli bir üs olarak kullandığına ve yaşamın sonraki dönemlerinde psikolojik gelişim için önemli bir temel oluşturduğuna inanmaktadır (Adler-Tapia 2012, 43). Güvenli bağlanma, keşif ve bağımsızlık ile ilişkilidir. Güvenli bağlanma ilişkisinde bebekle kurulan iletişimde bebeği engellemek yerine özerklik teşvik edilir. Bakım veren kişi uygun, hassas, öngörülebilir ve ilişkileri tamir edebilir şekilde yaklaşır. İlişsi, dünyayı keşfetmek için güvenli bir temel oluşturur. Güvenli bir bağlanma geliştiren çocuk, esneklik, bağımsızlık, uyma, empati, duygularını kontrol etme, sosyal yeterlik, olumlu duygular ve sağlıklı özgüven açısından daha avantajlidir (Taylor 2010, 28).

Kaygılı Kaçınan Bağlanma: Kaygılı kaçınan bağlanma ilişkisi gösteren bebekler, annelerinden ayrılıp yeniden bir araya gelme aşamasında anneleriyle temastan kaçınırlar veya etkileşim çabasını görmezden gelirler. Bebeklerin davranışlarından, annelerinin ihtiyaç duyduğunda orada olmayacağını bekledikleri düşünülür. Yalnız kaldıklarında diğer bebeklere göre daha az stresli tepkiler gösterir. Bebeğiyle kaygılı kaçınan bağlanma ilişkisi gerçekleştiren annelerin 
bebeklerini reddetmiş hatta bebeklerine karşı kızgınlık duygusu hissediyor olduğu düşünülür. Bebeklerini tutmak ve kucaklamak için diğer annelerden daha az zaman harcarlar ve etkileşimlerinin çoğu tatsız ve hatta acı vericidir (Newman \& Newman 2012, 165).

Kaygılı Kararsız/Dirençli Bağlanma: Bu bağlanma ilişkisini gerçekleştiren bebekler ayrılıktan önce ebeveyni ile yakınlık kurmak ister ve sıklıkla etrafını keşfetmeye çalışmaz. Ebeveyn ayrıldığında çoğu kez streslidirler ve geri döndüklerinde yapışma ile karışık öfkeli ve dirençli davranışlar sergilerler. Kucağa alındıklarında mücadele ederler ve bazen vurma ve itme davranışları gösterirler. Çoğu bebek kucaklandıktan sonra da ağlamaya devam eder ve kolay kolay avutulamaz (Berk 2015, 267).

Dağınık/Dezorganize Bağlanma: Bağlanma davranışlarının tahmin edilemez olduğu ve Ainsworth'ün belirttiği bağlanma çeşitlerine uymayan bağlanma özelliklerinin görüldüğü bağlanmadır (Levine \& Munsch 2011, 360). Çok rahatsız edici bakım modellerine cevap olarak, dağını/dezorganize bağlanma ilişkisi geliştiren çocuklar ihtiyaçlarını ve duygularını anlama veya ifade etme konusunda tutarlı yöntemler geliştiremezler (Cummings et al. 2003).

Tablo 1. Yabancı Durum Testinde Gözlenen Bağlanma Çeşitleri

\begin{tabular}{ll}
\hline Bağlanma Türü & Çocuğun Tepkileri \\
\hline Güvenli & Çocuk güvenli görünür ve bakıcıyı çevreyi \\
Bağlanma & keşfetmek için güvenli bir üs olarak kullanır.
\end{tabular}

\begin{tabular}{ll}
\hline Kaygılı Kaçınan & Çocuk çekingen görünür ve anne odaya \\
Bağlanma & döndügünde anneden kaçınarak güvensizlik \\
& gösterir.
\end{tabular}

Annenin Tepkileri

Anneler bebeklerin ihtiyaçlarına cevap verir. Ebeveyn-çocuk bağ 1 tutarlı ve sağlıklıdır.

Anneler bebeğin ihtiyaçlarını çok az karşılar ve tek başına olması için bebeği cesaretlendirir. Anneler ağlamayı kabul etmez ve çocuğun yetenekleri hakkında mantıklı olmayan beklentilere girer.

\begin{tabular}{|c|c|c|}
\hline $\begin{array}{l}\text { Kaygılı } \\
\text { Kararsız/Dirençl } \\
\text { i Bağlanma }\end{array}$ & $\begin{array}{l}\text { Çocuk annesine yapışarak, onu tekmeleyerek, } \\
\text { direnç gösterir ve mücadele ederek } \\
\text { güvensizlik davranışları sergiler. Çocuk, } \\
\text { annenin geri dönüşünde ya kararsılılı sergiler } \\
\text { ya da dirençli davranır. }\end{array}$ & $\begin{array}{l}\text { Anne, bebeğin ağlaması } \\
\text { karşısında yavaş veya tutarsız } \\
\text { tepki verir. Bebeğin ihtiyaçları } \\
\text { tutarlı karşılanmaz ve annenin } \\
\text { tepkileri önceden kestirilemez. }\end{array}$ \\
\hline $\begin{array}{l}\text { Dağınık/Dezorga } \\
\text { nize Bağlanma }\end{array}$ & $\begin{array}{l}\text { Çocuk, korktuğunda güven duyacağı kişileri } \\
\text { ararken, yine korku yaratan kişilere sığınmak } \\
\text { zorunda kalır. Çocuk ne yapacağını veya } \\
\text { nereye yöneleceğini bilemez. Öngörülemez bir } \\
\text { çevrede yaşadığı için çevreden ne } \\
\text { bekleyeceğini ve kendisinden ne } \\
\text { beklenildiğini bilemez. }\end{array}$ & $\begin{array}{l}\text { Ebeveyn ihmal veya istismarı ve } \\
\text { yönetilemez korkularla } \\
\text { davranılır. }\end{array}$ \\
\hline
\end{tabular}

Bağlanma sadece çocukluk döneminde değil yetişkinlik döneminde özellikle romantik ilişkiler açısından oldukça önemlidir. Bu bölümde Hazan ve Shaver'ın, Bartholomew ve Horowitz ile Brennan, Clark ve Shaver'ın bağlanma modelleri ele alınacaktır.

Hazan ve Shaver (1990), yetişkinlikte aşk ve iş hayatındaki kişilerle bağlanmanın işlevsel olarak bebeklik ve erken çocukluk döneminde meydana gelen bağlanma süreci ile benzerliğe sahip olup olmadığını incelemişlerdir. Çalışmalarında, Bowlby ve Ainsworth'ün bağlanma teorisinin temel bileşenlerini üç faktör halinde (kaçınan, kaygılı ve kararsız ile güvenli) araştırmalarına katılan yetişkinlere uygun olup olmadığını sormuşlardır. Yaptıkları çalışma sonucunda, yetişkin bağlanma sürecinin bebeklik/erken çocukluktaki bağlanma dinamikleriyle 
benzer olduğunu belirtmişlerdir. Bartholomew ve Horowitz, yetişkin bağlanma yönelimlerindeki bireysel farklılıkları değerlendirmek için iki boyutlu yetişkin bağlanma modelinde Bowlby'nin içsel çalışma modelini sistematikleştirmiştir. Bartholomew (1990), benlik ve başkaları modellerinin olumlu ya da olumsuz olmasına göre dört temel bağlanma örüntüsü tanımlamıştır. Olumlu benlik modeli, başkalarının onayından bağımsız olarak gelişmiş yüksek özsayg1 ve kuşku duyulmadan kabul edilen içselleştirilmiş bir "sevilebilirlik" duygusu olarak tanımlanabilir. Olumsuz benlik modeli ise düşük özsaygı ve başkalarından onay alma gereksinimi olarak tanımlanabilir. Olumlu başkaları modeli, başta bağlanma kişisi olmak üzere kişi için önemli olan başkalarının "güvenilir" ve gerektiğinde "ulaşılabilir" olduğuna ilişkin olumlu beklenti ve inançları içerir. Olumsuz başkaları modeli ise başkalarının "güvenilmez" olduğuna ilişkin kronik inanç ve ön kabulden beslenen yakınlık kurmaktan kaçınma, sosyal destek alma ve verme konusunda kayıtsız kalma ve yakın ilişkilerden olumsuz beklentiler taşıma gibi tutum ve davranışları barındırır (akt. Sümer 2006, 3-4). Bağlanma örüntüleri aşağdaki gibi açıklanmıştır:

Güvenli bağlanma (kendine ve başkalarına olumlu bakış açısı), yüksek özgüven ve başkalarıyla yakın bağları kurma ve sürdürme yeteneği ile karakterize edilir.

Saplantılı bağlanma (kendine olumsuz, diğerlerine olumlu bakış açısı), benlik değerinin düşük olması, başkalarının yakın ilişkilerde sevgisine ve onayına aşırı bağımlılık ve aşırı talepkâr kişilerarası bir tarz ile karakterizedir.

Kayıtsız bağlanma (kendine olumlu, diğerlerine olumsuz bakış açısı), zorlayıcı bir özgüven ve yakın ilişkilere önem vermeme ile karakterize edilir.

Korkulu bağlanma (kendine ve başkalarına olumsuz bakış açısı), düşük öz saygı ve reddedilme korkusundan dolayı aktif yakınlıktan kaçınma ile karakterizedir. Bununla birlikte, bu korku, sosyal temas ve onaylanma isteğiyle birleşmekte, bu da yakınlık ve mesafenin çelişkili ihtiyaçlarıyla sonuçlanmaktadır (akt. Henderson et al. 2005, 220).

Bartholomew ve arkadaşlarının çalışmalarını izleyen diğer çalışmalarda da genellikle bağlanma boyutlarının kategorilerden daha betimleyici olacağı öne sürülmüş ve temel boyutlar düzeyinde bağlanma stillerinin tanımlanması yaygın olarak kabul görmüştür (Brennan et al. 1998 akt. Sümer 2006, 4).

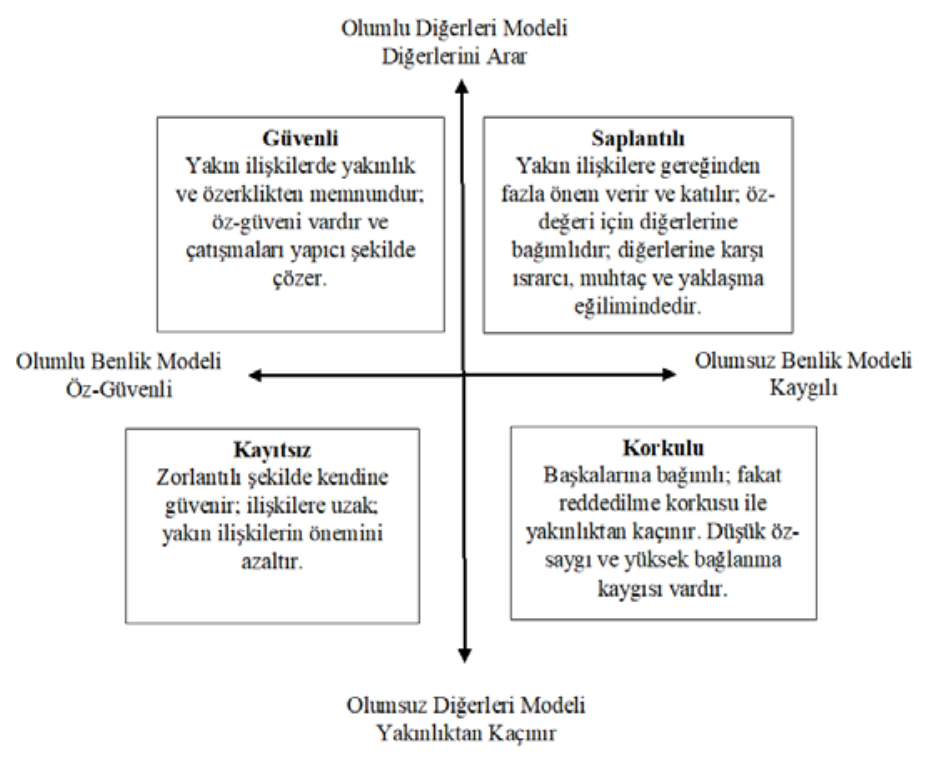

Fig 1. Bartholomew’nun İki Boyutlu Dört Kategorili Bağlanma Şeması (Henderson et al. 2005, 220) 
$\mathrm{Bu}$ doğrultuda, bağlanma tarzı, bağlanmadan kaçınma ve bağlanma kaygısı olarak adlandırılan iki boyut olarak kavramsallaştırılmıştır. Bağlanmadan kaçınma, yakınlık kurmaktan duyulan rahatsızlık, başkalarına bağlanmada güven eksikliği ve aşırı bir özgüven ile karakterizedir. Bağlanma kaygısı, aşırı onaylanma ihtiyacı, ilişkiye ilişkin meselelerle meşgul olma ve terk edilme korkusu ile karakterizedir. Hem bağlanmadan kaçınma hem de endişe düzeyleri düşük olan bireylerin güvenli bir şekilde bağlandığı ve duygusal yakınlıkta rahatlık, yakınlarına güvenme ve güvensizlik yaşayan bireylere göre daha uzun süre tatmin edici ilişkiler yaşadıkları belirtilmektedir (Brennan et al. 1998 akt. Gillath \& Karantzas 2015, 133). Bartholomew ve Horowitz (1991), dört bağlanma stilini temel boyutların kesişme noktalarında tanımlamıştır. Bu dört bağlanma tarzı, modern araştırmacıların sıklıkla bağlanma kaygısı ve bağlanmadan kaçınma olarak adlandırdıkları iki ana boyuta göre temsil edilir (ör. Brennan et al. 1998). Bağlanma kaygısı, düşük öz değer ve terk edilme ve reddedilme korkusuyla karakterizedir.

\section{Bağlanmayı Etkileyen Faktörler}

Erken dönemden itibaren oluşmaya ve gelişmeye devam eden bağlanmada kültürel özellikler, aile stresi, bakımın niteliği ve bebeğin mizacı, anne-baba (bakım verenin) kendi bağlanma tarzı, bakım verenin duygusal durumu gibi faktörler önemli rol oynamaktadır:

\section{Kültürel Faktörler}

Bağlanma tüm kültürlerde aynı mıdır yoksa evrensel midir? Kültürler arası araştırmalar bağlanma örüntülerinin bazı kültürlerde farklı biçimde yorumlanabileceğini göstermektedir (Berk 2015, 268). Bağlanma teorisi, insanların başka bir kişiyle yakınlaşma arayışı içinde psikolojik bir eğilime sahip olduklarını ve kişi bulunduğunda kendilerini güvende hissettiklerini ve kişi yokken endişeli olduklarını iddia eder. Bağlanma teorisinin temel ilkeleri arasında, bir bakıcının bebeğe karşı duyarlılığının güvenli bir bağlanmaya; bebeklik döneminde ve erken çocuklukta güvenli bir şekilde bağlanmanın da sosyal yetkinliğe yol açtığı ve güvenli bir şekilde bağlanan çocukların dış dünyayı keşfetmede bakıcıyı güvenli bir temel olarak kullandıkları belirtilmektedir (Rothbaum et al. 2000). Bağlanma konusunda farklı ülkelerde yapılan çalışmalar göz önünde bulundurulduğunda örneğin, Alman bebeklerin Amerikan bebeklerden belirgin biçimde daha fazla kaçınan bağlanma gösterdiği görülmektedir (Grossman et al. 1985 akt. Berk 2015, 268). Buna karşın Afrika Mali’de Dogon topluluğu bebekleriyle yapılmış bir çalışma bebeklerin hiçbirinin annesine kaçınan bağlanma göstermediğini ortaya koymuştur (True et al. 2001 akt. Berk 2015, 268). Japon anneler bebekleri ile sürekli yakınlık içindedirler. Bebeklerin çevredeki insanları ve nesneleri değerlendirmek için annelerinin tepkilerini izlemeleri beklenir. Japon anneler, bebeklerin oyun davranışını, mimiklerle ve yüz ifadeleriyle ustaca yönlendirir (Newman \& Newman 2012, 168). Rothbaum, Weisz, Pott, Miyake ve Morelli (2000), Amerika Birleşik Devletleri ve Japonya'daki kültürel değerleri karşılaştırmış ve bağlanma kuramının ilkelerinin, güvenli bağlanma ve sosyal yetkinlik inşası gibi Batı kültürünün değerlerini ve anlamını yansıttı̆̆ını iddia etmiştir. Bir çocuğun özerkliğinin kültürel değerinin, ebeveynler tarafından verilen duyarlı bakımın anlamını etkilediğini savunmaktadırlar. Ayrıca, bakım veren duyarlılığın değeri bir kültürden diğerine farklılık gösterir. İki kültürdeki anneler çocuklarıyla farklı iletişim kurarlar. Japonya'da erken etkileşimler daha fazla duyguya dayalıdır; ABD'de ise daha fazla bilgi temellidir.

Batı dışındaki kültürlerin çoğunda, örneğin, grup hedeflerine karşılıklı bağımlılığın ve bağımsızlı̆̆ın ve öz hedeflerin öncelikli olduğu Çin, Mısır, Kore ve Türkiye toplumlarında, psikolojik kontrol, karşılıklı bağımlılığ1 aşılamak için normal olarak kullanılır. Çocukta itaat (Kağıtçıbaşı 1970; Shek 1998; Rudy \& Grusec 2001) ve genellikle sıcak ebeveynlik bağlamında ortaya çıkar (Kağıtçıbaşı 1970; Güngör 2008). Chao’ya (1994) göre, Çin’deki psikolojik kontrol, yetişkin merkezli cezadan ziyade çocuk merkezli eğitim ile ilgilidir ve çocuğu başka- 
larıyla ilişkisel uyum ve gömülülük içinde sosyalleştirmeyi amaçlamaktadır. Aynı şekilde, ebeveyn, özellikle babalık, kontrol ve otorite, Türk ailelerinde hedefe yöneliktir ve çocuğun sosyal olarak uygun görgü ve karşılıklı bağımlılık edinmesine ilişkin olarak özellikle vurgulanır (Kağıtçıbaş1 2007). Diğer bir deyişle, Türk ebeveynler kısıtlama ve kontrol uygulamalarında, bağlanmadan kaçınma özelliğini belirleyen mesafeden ziyade, kişilerarası yakınlığa yönelik sosyal uyum ve beklentileri vurgulamaktadır (akt. Güngör \& Borstein 2010, 3).

\section{Aile Stresi}

Ebeveyn depresyonu bağlanma açısından bir risk faktörüdür. Depresyondaki bir ebeveyn bebeğin işaretlerine hızlı ve sıcak bir şekilde karşılık vermede zorlanabilir. Normal gelişen çocukları olan ciddi depresyondaki veya kaygılı olan annelerin bebeklerinin bağlanma problemi yaşadıkları belirtilmektedir (Lyons-Ruth et al. 1990 akt. Trawick-Smith 2014, 178). Bağlanmanın güvenli olmasını etkileyen bir diğer faktör yoksulluktur. Yoksulluk bebek hastalıklarına neden olabilir. Sürekli ev değiştirmek, çocuk bakımında ani değişiklikler, ebeveyn stresi, ebeveyn depresyonu ve bebeğin ihtiyaçlarına duyarsızlık gibi nedenlere yol açan yoksulluk ebeveyn-bebek bağlanmasını engelleyebilir (Trawick-Smith 2014, 178).

\section{Bakımın Niteliği}

Bağlanma ilişkisinde bakımın niteliği daha çok bakım veren kişi/kişilerin davranışları çercevesinde ele alınmaktadır. Bir bebeğin birincil bakım veren kişiye olan bağl1lığının kalitesinin, büyük ölçüde, aldığı ilgi türüne bağlı olduğuna inanılmaktadır. Güvenli bir şekilde bağlanmış bebeklerin annelerinin en başından itibaren hassas ve duyarlı bakıcı oldukları düşünülmektedir. Bakım veren kişi bebeğine karşı olumlu bir tutuma sahipse, ihtiyaçlarına karşı duyarlıysa, kendisiyle etkileşimli bir senkronizasyon oluşturmuşsa ve geniş bir uyaran ve duygusal destek sağlamışsa, bebek genellikle etkileşimlerinden rahatlık ve zevk alır ve bakım veren kişiyle güvenli bir şekilde bağlanmaları muhtemeldir. Güvenli bir bağlanma biçiminden ziyade dirençli olan bebekler genellikle bakımlarında tutarsız olan ebeveynlere sahiptir. Bebek, duygusal destek ve rahatlık elde etmek için sarılmak, ağlamak ve diğer bağlanma davranışlarını çaresizce deneyerek bu tutarsız bakımla baş edebilir ve bu çabalar genellikle başarısız olduğunda kızar ve kederlenir (Shafffer \& Kipp 2007, 460).

\section{Bebeğin Mizacı}

Mizaç, çocuğun kişi ve olaylara cevap verme biçimini etkileyen biyolojik kökenli bireysel farklılıklardır. Kişiliğin gelişimini oldukça etkileyen mizacın bireylerin davranışlarını çok çeşitli ortamlarda etkilediği bilinmektedir (Taylor 2010, 25). Bağlanma araştırmacıları geleneksel olarak bağlanma ilişkisinde bakıcıların tutumlarına odaklanmış olsa da, bebekler de ebeveynçocuk etkileşimi kalıplarının oluşumunda önemli bir rol oynamaktadır (Roth-Hanania \& Davidov 2004, 197). Bağlanma, bakım veren kişi/kişilerle bebek arasında oluşan etkileşim bağlamında meydana geldiği için bebeğin bir iletişim ortağı olarak kendi tarzının duygusal bağın büyümesine önemli ölçüde katkıda bulunduğu kabul edilmektedir (Bukatko \& Daehler 2004, 408). Mizaç, örneğin bebeğin sıkıntıya yatkınlığı (zorluk, duygusallık, olumsuz tepkisellik) ve sıkıntıyı etkili bir şekilde düzenleme yeteneğiyle ilgilidir. Bu nedenle, bu geçici özelliklerin bağlanma güvenliğinin geliştirilmesi üzerindeki potansiyel etkisi çok fazla araştırmanın konusu olmuştur (Roth-Hanania \& Davidov 2004, 197-198). Bu konuda yapılan çalışmalarda bebeğin huzursuzluk, sinirlilik ve sıkıntıya eğilimli olmasının güvensiz bağlanma ile ilişkili olduğu belirtilmiştir (van den Boom 1994, 1995 akt. Bukatko \& Daehler 2004, 408). Bağlanma ilişkisinde bebeğin mizacı önemlidir ancak, bağlanmanın nasıl gerçekleştireceğini tek başına belirlememektedir (Bukatko \& Daehler 2004, 408). 


\section{Evlat Edinme}

Evlat edinme, durumu evlat edindirilmeye uygun bir çocukla, durumu evlat edinmeye uygun kişi/eşler arasında hukuki bağlar sağlanarak çocuk ebeveyn ilişkisinin kurulmasıdır. Ülkemizde evlat edinme, "Korunma altındaki bir çocuğun evlat edinilmesi” ve "Kişilerarası anlaşma ile evlat edinme" olmak üzere iki yolla yapılmakta ve Aile, Çalışma ve Sosyal Hizmetler Bakanlığ Çocuk Hizmetleri Genel Müdürlüğü tarafından yürütülmektedir. Evlat edinmede aşağıdaki koşullar aranır:

- Küçüğün, evlât edinen tarafından en az bir yıl süreyle bakılmış ve eğitilmiş olması,

- Evlât edinmenin her halde küçügün yararına bulunması ve evlât edinenin diğer çocuklarının yararlarının, hakkaniyete aykırı bir biçimde zedelenmemesi,

- Evlât edinecek kişi veya eşlerin, evlât edinilenden en az on sekiz yaş büyük olması,

- Ayırt etme gücüne sahip olan küçügün rızasının alınması,

- 22/11/2001 tarihli ve 4721 sayı1ı Türk Medenî Kanununun 311'inci ve 312'nci maddelerinde yer alan hükümler hariç, 309'uncu maddesinde belirtilen şekilde küçüğün ana ve babasının rızasının bulunması,

- Küçügün vesayet altında olması halinde, Türk Medenî Kanunu'nun 397’nci maddesinde öngörülen vesayet dairelerinin izninin alınmış olması,

- Eşlerin en az beş yıldan beri evli olmaları veya her ikisinin de otuz yaşını doldurmuş bulunmaları (Çocuk Hizmetleri Genel Müdürlüğü 2019).

Kendi ailesi ile yaşama şansı kalmamış olan çocuklar için "Evlat Edinme Hizmeti" en uygun bakım olarak değerlendirilmektedir. Bağlı kuruluşlarda bulunan korunmaya muhtaç çocuklardan durumu evlat edinme hizmetinden yararlandırılmaya uygun olanlar, yapılan değerlendirme sonucu haklarında evlat edinmelerine ilişkin olarak uygun kanaat bildirilen aileler yanına evlat edinme hizmetinden yararlandırılmak üzere yerleştirilir. Türk Medeni Kanunun 305'inci maddesi gereği bir yıllık geçici bakım sürecinde yapılan izlemeler sonucu uygun kanaat oluşması halinde ise mahkeme kararı ile evlat edinilen küçük evlat edinenin nüfus kütügüne işlenerek soyadını alır ve öz çocuk gibi eşit haklara sahip olur (ASPB 2013).

\section{Evlat Edinilen Çocuklarda Bağlanma Süreci}

Evlat edinilen çocukların, evlat edinmeden önce ihmal ve istismara maruz kalma olasılıkları ve sosyal, duygusal, davranışsal risk faktörlerinin daha yüksek olması nedeniyle evlat edinen ebeveynlerin evlat edindikleri çocuklarla bağlanma ilişkisini kurarken biyolojik ebeveynlere göre daha çok zorlandıkları bilinmektedir (Lionetti et al. 2015).

Evlat edinilen çocuklarda korkusuz veya dikkatsizce yabancılar dahil olmak üzere tüm yetişkinlere karş1 şefkatli ve arkadaşça davranmak anlamına gelen "ayrım gözetmeyen samimiyet" gözlemlenmiştir. Bu gibi durumlarda çocukların bağlanma figürüne olan davranışları ile diğer yetişkinlere yönelik davranışları ayırt edilemez (Chisholm 1998). Evlat edinilen çocuklar bağlanma bozukluğu davranışlarında daha risklidirler (O’Connor et al. 1999, 2000). Mental Bozuklukların Tanısal ve Sayımsal El Kitabı, üçüncü ve dördüncü baskısında (DSM- III ve IV) "Tepkisel Bağlanma Bozukluğu” olarak tanımlanan bağlanma bozukluğunun en önemli belirtisi, bebeğin ya da küçük çocuğun yaşamındaki pek çok alanda önemli ölçüde bozulma ve gelişim dönemlerine göre uygunsuz toplumsal ilişki kurma biçiminin olmasıdır. Ayrıca, kalıcı bağlanmanın kurulmasını önleyici şekilde birincil bakıcının sık sık değişmesi ya da çocuğun temel ihtiyaçlarının, sosyal ve duygusal gereksinimlerinin sürekli göz ardı edilmesi de bozukluğun ölçütleri içerisinde yer almaktadır (Soysal et al. 2009, 2048).

Evlat edinme açısından yaş önemli bir faktördür. Bir yaşından sonra evlat edinilmiş çocuklar, evlat edinilmeden önce genellikle birincil bakıcıları ile ihmal, reddedilme, fiziksel, 
psikolojik ve cinsel istismara kadar çok çeşitli zorluklar yaşama riskine sahip olan çocuklardır. Erken dönemdeki olumsuz deneyimler nedeniyle, geç evlat edinilmiş çocuklar, evlat edinen ebeveynlerine karşı çelişkili ve meydan okuyan davranışlar sergilemelerine neden olan güvensiz veya düzensiz bağlanma ve yeni bakıcılarıyla sevgi dolu bağlar yaratma şansını ciddi biçimde zorlamaktadır (Vorria et al. 2003). Juffer, Bakermans-Kranenburg ve van IJzendoorn (2005), evlat edinilen çocukların bağlanma süreçlerini inceledikleri çalışmalarında bebeklerin \% 74'ünün bakım verenlerle 12 aylıkken güvenli bağlanabildiklerini, \% 22'sinin ise dağını/ dezorganize bağlanma yaşadıklarını saptamışlardır. Bu çocukların büyük kısmının güvenli bağlanmasındaki en önemli etkenlerden birisinin ortalama 11 haftalıkken evlat edinilmeleri olmuştur.

Çavuşesku döneminde Romanya'nın nüfusunun artması için çok çocuk yapılması yasa ile zorunlu hale getirilmiş, ekonomik, sosyal problemler ve rejim baskısı gibi nedenlerle binlerce çocuğa bakılamamış ve yetimhaneler tek alternatif olarak görülmüştür. Çavuşesku rejimi 1989 yılında yıkıldığında yaklaşık 65.000 çocuğun yetimhanelerde yaşadığı görülmüş, 1990’lı yılların başında bunların birçoğu Batılı ailelerce evlat edinilmiştir. Beyin gelişiminin çok hızlı olduğu dönemde, 1 yaşından önce, kuruma alınan ve 6 aydan daha fazla kurumda kalan çocukların daha dirençli problemler yaşadıkları görülmüştür (Davies 2011). Romanya'daki yetimhanelerde kalan ve 3-5 yaşlarındayken Kanada'daki aileler tarafından evlat edinilen çocuklardan 3 yaşındaki çocukların \% 30'unun, 5 yaşındaki çocukların \% 42'sinin güvenli bağlanma ilişkisi kurabildikleri görülmüştür (Marcovitch et al. 1997). Yunanistan'da yetimhanede kalan çocukların evlat edinilme süreçleri incelendiğinde, evlat edinilen çocuklarda biyolojik ebeveynleriyle büyüyen çocuklara göre yüksek oranda dağınık/dezorganize bağlanma $(\% 66)$ görülmüştür (Vorria et al. 2003). 2.912 evlat edinilmiş çocuğun yer aldığ 39 araştırmadan yapılan meta analiz çalışmasında evlat edinilen çocukların evlat edinilmeyen çocuklara göre daha az güvenli bağlanma gerçekleştirdikleri belirlenmiştir (van den Dries et al. 2009). Evlat edinilen çocuklarla evlat edinen aileler arasındaki bağlanma ilişkisinin süreç içerisinde olumlu anlamda geliştiği bilinse de bazı araştırmalarda çocuklara sağlanan olumlu deneyimlerin önceki olumsuz deneyimlerin etkisini tamamen silemediğini göstermiştir. Örneğin, güvensiz bağlanma deneyimlerine bağl1 zihinsel temsillerin evlat edinme sonrası üçüncü yılında bile devam ettiği görülmüştür (Hodges et al. 2005).

Evlat edinilen çocuklarla evlat edinen ailelerin bağlanma ilişkilerini olumsuz anlamda etkileyen bazı durumlar olabilir. Örneğin evlat edinilen çocuğun biyolojik annesinin doğum öncesi dönemde alkol, uyuşturucu madde kullanması, kötü muameleye maruz kalması söz konusu olabilir. Yine, gebeliğin istenip istenmediği; evlat edinilen çocuğun kötü muameleye maruz kalması, evlat edinilen çocuğun bağlanma öyküsü ve evlat edinilme sonrası ebeveynlerin ebeveynlik davranışları da etkili olabilir (Levy \& Orlans 2000). Çocukların davranışsal problemleri ve gelişimsel gecikmeler, yüksek ebeveynlik stresi düzeyleri (Judge 2004), daha düşük ebeveyn memnuniyeti seviyeleri (Mainemer et al. 1998) daha yüksek düzeyde güvensiz bağlanma ile ilişkili bulunmuştur (Chisholm et al. 1995; Zeanah 2000; Judge 2004). Evlat edinilen çocukların davranışsal özellikleri bağlanmayı etkileyen önemli bir faktördür. Örneğin evlat edinilen çocuğun bilişsel işlevlerinin kısıtlı olması, konuşma ve dil gelişimlerinde gecikme, motor gelişimde bozukluk, öz-düzenleme ve özerk işlevlerin düşük olması da bir risk faktörüdür (Remkus 1991). Evlat edinilmiş çocuklarda gözlenen yaygın duygusal problemler arasında kaygı ve korku; yaygın davranış sorunları arasında uyumsuzluk, saldırganlık, aşırı hareketlilik, yalan söyleme ve hırsızlık yer almaktadır. Evlat edinilen çocukta gözlenen bu durumlar bağlanma ilişkisini olumsuz etkileyebilir. Bu konuda yapılan boylamsal çalışmalarda evlat edinilen çocuklarda aşırı hareketlilik gibi davranışların devam etme; aşırı öfkeli davranışların ise azalma olasılığının olduğu belirtilmektedir (Rushton 2004).

Evlat edinme bağlamında ebeveyn beklentileri de bağlanma ilişkisinde önemli bir faktör 
olarak karşımıza çıkmaktadır. Biyolojik ebeveynlikte de ebeveyn beklentileri oldukça önemlidir ancak, evlat edinme sürecinin benzersiz dinamikleri nedeniyle evlat edinmede bu süreç farklı olabilir. Evlat edinilen çocuktan beklentiler ile çocuğun özellikleri örtüşmediğinde bu durum evlat edinen ebeveynleri olumsuz anlamda etkileyebilmektedir (Foli et al. 2017). Evlat edinen anne babaların ebeveyn yetkinlik algılarında başarısızlıklar yaşadıklarında suçluluk duyabildikleri, evlat edindikleri çocuğa kendilerinin sevgi dolu bakımına cevap veremediği için öfke duyabildikleri, çocuğun genetik özellikleri hakkında endişe duyabildikleri, çocuk ile ilgili çelişik duygular hissedebildikleri ve evlat edinme ilgili pişmanlıklar yaşayabildikleri belirtilmektedir (Lieberman 2003). Evlat edinen ebeveynlerin ve biyolojik ebeveynlerin çocuklarıyla iletişimlerinde sıcaklık ve olumsuzluk duygularını inceleyen araştırmalar incelendiğinde, bazı çalışmaların evlat edinen ebeveynlerin daha uzak ve olumsuz ilişkiler kurduğunu (Braungart 1994), bazı çalışmalarda bu konuda herhangi bir farkın olmadığını belirten çalışmalar bulunmaktadır (Glover et al. 2010). Öte yandan, bir dizi çalışma, evlat edinen ailelerin evlat edinilmiş çocuklarda ve ergenlerde "kazanılmış" güvenliği sağlamadaki rolünü vurgulamaktadır. Beijersbergen ve diğerleri (2012), 125 erken evlat edinilmiş ergen üzerinde gerçekleştirdikleri bir araştırmada annenin gösterdiği duyarlı desteğin, bebeklikteki güvensiz bağlanmadan ergenlikte güvenli bağlanmaya kadar bir değişiklik meydana getirdiğini ortaya koymuştur. Benzer şekilde, Schoenmaker ve arkadaşları (2015), yaptıkları boylamsal çalışmalarında bebeklikten 23 yaşına kadar geçen sürede evlat edinilen çocukların bağlanma süreçlerini incelemişlerdir. Bebeklik döneminde, 7 ve 14 yaşında bağlanma ilişkileri incelenen yetişkinlerin bebeklik döneminde evlat edinen anneleri tarafından duyarlı yaklaşılanların bebeklik, çocukluk ve genç yetişkin dönemlerinde güvenli bağlanma ilişkisi geliştirebildikleri görülmüştür.

Çocukluklarında başka ülkelerden İsveç'e evlatlık verilen 40 yetişkinin bağlanma süreçlerinin incelendiği bir çalışmada, geç dönemde evlat edinilenler ve biyolojik kökenleri hakkında yoğun soru işaretleri olanların güvensiz bağlandıkları görülmüştür. Ayrıca, evlatlık olmadan önceki anılar, biyolojik anne babalarının boşanması, evlat edinen ailenin çocuğun biyolojik akrabaları ile iletişim eksikliği, evlat edinilenlerde biyolojik geçmişleri hakkında düşünmeme eğilimi gibi faktörlerin olumsuz etkileri bildirilmiştir (Irhammar \& Bengtsson 2004). Evlat edinme sürecinde, evlat edinen aile ile çocuğun biyolojik ailesi arasında ilişkinin kurulup devam etmesinin önemli olduğu bildirilmektedir. Çocuğun bakış açısından, böyle bir ilişkinin varlığı, kafasındaki sorulara yanıt bulması, biyolojik köklerini bilmesi, kendisini doğuran ebeveyninin zorlukları hakkındaki anlayışını artırması, kendi kendisini suçlamayı azaltması ve kimlik sorunlarını çözmesi bakımından önemli olduğu vurgulanmaktadır (Jones 2016, 87).

Ülkemizde evlat edinilen çocuklarda bağlanma konusunda Altınoğlu-Dikmeer, Erol ve Gençöz'ün (2014) yürüttükleri çalışmada, evlat edinilmiş ve biyolojik ailesi yanında yaşayan çocukların bağlanma ilişkileri incelenmiştir. 6-18 yaşları arasındaki 61 evlat edinilmiş ve 62 biyolojik ailesi yanında yaşayan çocuğun ve anne babasının katıldığı çalışmada, bağlanma açısından herhangi bir fark ortaya çıkmamıştır. Yurtdışında ve ülkemizde yapılan çalışmalar göz önünde bulundurulduğunda farklı sonuçların ortaya çıktığı görülmüştür. Sonuçların farklı çıkması kültürel etkenlerden kaynaklı olabilir. Ülkemizde, evlat edinen ailelerinden gördükleri sevgi, ilgi ve bakım sayesinde olumlu bağlanma ilişkileri meydana gelmiş olabilir. Bu konuda yapılacak başka çalışmalar bu durumun nedenlerini daha net ortaya koyabilir.

\section{Sonuç ve Öneriler}

Evlat edinmek, biyolojik bir çocuğa sahip olmaktan daha zorlu süreçleri beraberinde getirir. Bunun için çoğu evlat edinen ebeveyn, özellikle çocuğun duygusal ve psikolojik sorunları hakkında hazırlıklı hissetmediklerini bildirmektedir. Biyolojik annelerin aksine, evlat edinen annelerin hamilelik yaşamadıkları için ebeveynlerin, ebeveynliğe ait doğal aidiyet uyum sürecini 
yaşayamadıkları (Drozd et al. 2018) ve evlat edinen çoğu annenin bebeklerini emziremediği göz önünde bulundurulduğunda evlat edinen ebeveynlerle evlat edinilen çocuklar arasındaki bağlanma ilişkisinin çok kolay ve güvenli kurulamaması da anlaşılabilir.

Edens ve Cavell (1999)'a göre, bağlanma, pek çok yakın ilişkiyi karakterize eden ve bir rahatlık ve güvenlik duygusu sağlayan sevgi bağını ifade eder. Bu nedenle evlat edinen bireylerin evlat edindikleri çocuklarla "sağ lıklı" ilişki kurmaları için bağlanma ilkelerinin benimsenmesi gerektiğini belirtmektedir. Evlat edinilen bebekler, doğum öncesi veya doğum komplikasyonları ve ebeveyn psikopatolojisi riski altında olabilirler. Bu tür riskler, evlat edinen ebeveynlerin rolünü daha zor hale getiren belirli bağlanma davranışlarının (örneğin tutulmasından hoşlanmayan) olasılığını artırabilir. Evlat edinen ebeveynler, aynı zamanda, bağlanma sürecine müdahale edebilecek rol yükümlülükleri konusunda rol özerkliği ve belirsizlik eksikliği yaşayabilirler. Yani, evlat edinen ebeveyn rolüne geçiş, biyolojik ailelerde görülmeyen çeşitli ebeveyn rolü engelleri ortaya çıkarabilmektedir. Ayrıca, evlat edinme statüsünün açıklanması (zamanlamasına ve tarzına bağlı olarak) evlat edinen ailenin "ait olmadıklarını" hissetmelerine neden olabilir.

İlgili yazın incelendiğinde, birçok evlat edinme işleminin başarılı olmasına rağmen, bazı evlat edinen ebeveynlerin evlat edinme sürecinin bitiminden sonra çok çeşitli zorluklarla karşılaşabildiğini göstermiştir (Drozd et al. 2018). Evlat edinen ebeveynlere yönelik yapılan müdahale programları ile evlat edinen ebeveynlerde empatinin arttığı; evlat edinilen çocuklarda davranış problemlerinin azaldığ ve evlat edinen ebeveynlerle evlat edilen çocuklarda güvenli bağlanma ilişkisi özelliklerinin ortaya çıktığı görülmüştür (Juffer et al. 2007; Benjamin 2010; Wassall 2011; Carnes-Holt \& Bratton 2014; Baker et al. 2015).

Evlat edinen ebeveynlere yönelik bağlanmaya dayalı müdahale programları, evlat edinen ebeveynlerin evlat edindikleri bebek/çocuklarıyla güvenli bağlanma sürecini desteklemesi bakımından oldukça önemlidir. Bu programlarda ebeveynlerin bebek/çocuklarına karşı duyarlılıklarını artırarak bebek/çocukların yeterliklerin artması ve güvenli bağlanma ilişkisinin oluşması desteklenmektedir. Örneğin ebeveynin bebek/çocuğunun verdiği sinyalleri doğru anlaması (örn., bebeğim benimle iletişime geçmek mi istiyor, yoksa çevresini mi keşfetmek istiyor?), bebeğin/ çocuğun verdiği sinyallere yerinde ve zamanında yanıt vererek bebeğin/çocuğun ihtiyaçlarının karşılanması ve bebeğin/çocuğun davranışlarının ortaya çıkardığı sonuçları fark etmesinin sağlanması için firsatların oluşturulmasının sağlanması teşvik edilir (Juffer et al. 1997, 1043). Bu nedenle, ülkemizde evlat edinme sürecinde Aile, Çalışma ve Sosyal Hizmetler Bakanlığ Çocuk Hizmetleri Genel Müdürlügü’nün standart ve kapsamlı işlemlerinin yanı sıra, "Bağlanmaya Dayalı Ebeveyn-Çocuk Müdahalesi” yaklaşımlarının sosyal çalışmacı, psikolog, çocuk gelişimci gibi meslek elemanlarından oluşan multidisipliner ekiplerle uygulanması son derece önemlidir. Kurumlarda yetişen çocukların güvenli bağlanma ilişkileri geliştiremedikleri göz önünde bulundurulduğunda evlat edinilmesi çocuğun ruh sağlığının korunması adına önemli bir girişimdir. Ebeveynlerin beklentileri, çocuğun olumsuz davranış risklerinin varlığ1, çocuğun yaşı gibi faktörler bir araya geldiğinde bağlanma sürecinin güvenli bir hal alması zaman gerektirebilir. Bağlanma sadece bakım veren ebeveyn ve yetişkinlerin değil bakım verilen bebeğin tepkileri ile de şekillenebilen bir süreçtir.

Evlat edinme sürecinin daha sağlıklı yapılabilmesi için ilk olarak evlat edinmenin mümkün olduğunca erken dönemde yapılması önemlidir. Bu durum bazı nedenlerden dolayı mümkün olmadığında, evlat edinen ebeveynlerin evlat edinilen bebek/çocukların olumsuz davranışları varsa, sabır, ilgi, duyarlılık gibi yaklaşımlarla bu davranışları olumluya doğru yönlendirilebilirler. Evlat edinme öncesi yapılacak hazırlıklar, evlat edinme ve çocuk yetiştirme adına gerçekçi beklentiler oluşturmaya yardımcı olabilmesi adına önemlidir. 
Çocuklar, içine doğdukları aileleri kendileri seçememektedirler. Çeşitli nedenlerden dolayı biyolojik ebeveynlerinden ayrı kalan çocukların sağlık, eğitim, bakım, ilgi ve sevgi ihtiyaçlarının sağlıklı bir biçimde karşılanabilmesi akıl ve beden sağlıklarının korunabilmesi ve gelişebilmesi açısından önemlidir. Çocuğun gelişiminde, doğuştan getirdiği özellikler kadar çevresel faktörler de önemlidir. Bu bakış açısıyla, bakıma ve korunmaya muhtaç olan çocukların aile ortamında büyüyebilmeleri için tüm toplumlarda evlat edinme süreçleri hakkında istek ve gönüllülük açısından farkındalık sağlanması oldukça önemlidir. Evlat edinme sürecinin daha sağlıklı sonuçlar ortaya çıkarabilmesi için de evlat edinen ebeveynlerle evlat edinilen çocuklar arasındaki güvenli bağlanma ilişkisi için gerekli eğitim, destek ve müdahalelerin yapılması bir o kadar önemlidir.

\section{KAYNAKÇA}

Adler-Tapia R. (2012). Child Psychotherapy: Integrating Developmental Theory into Clinical Practice. New York 2012.

Altınoğlu-Dikmeer İ., Erol N. \& Gençöz T. (2014). "Evlat Edinilmiş ve Biyolojik Ebeveyniyle Yaşayan Çocukların Davranışsal ve Duygusal Sorunları ve Bağlanma Düzeyleri ile Ana Babalarının Çocuk Yetiştirme Stillerinin Karşılaştırmalı Olarak Değerlendirilmesi”. Türk Psikiyatri Dergisi 25/4 (2014) 234-243.

ASPB (2013). Aile ve Sosyal Politikalar Bakanlı̆g 2013 Yll l Faaliyet Raporu. Kaynak: http://kutuphane.aile.gov.tr/Uploads/Arapor/2017_07_27_14_22_16_ed7b3e28-9086-4bc3-a84e99e33db15cba_10.pdf

Baker M., Biringen Z. Meyer-Parsons B. \& Schneider A. (2015). "Emotional Attachment and Emotional Availability Teleintervention for Adoptive Families”. Infant Mental Health Journal 36/2 (2015) 179192. Doi:10.1002/imhj.21498.

Bartholomew K. \& Horowitz L. M. (1991). "Attachment Styles Among Young Adults: A Test of a FourCategory Model”. Journal of Personality and Social Psychology 61 (1991) 226-244.

Bartholomew K. (1990). "Avoidance of Intimacy: An Attachment Perspective”. Journal of Social and Personal Relationships 7 (1990) 147-178.

Beeghly M. \& Cicchetti D. (1994). "Child Maltreatment, Attachment, and the Self System: Emergence of an Internal State Lexicon in Toddlers at High Social Risk". Development and Psychopathology 6 (1994) 5-30.

Beijersbergen M. D., Juffer F., Bakermans-Kranenburg M. J. \& van IJzendoorn M. H. (2012). "Remaining or Becoming Secure: Parental Sensitive Support Predicts Attachment Continuity from Infancy to Adolescence in a Longitudinal Adoption Study”. Developmental Psychology 48/5 (2012) 1277-1282. Doi:10.1037/a0027442

Benjamin J. L. (2010). Biopsychosocial-Based Versus Behavioral-Based Parenting Model: A clinical Trial for Adoptive Parents with Attachment-Challenged Children. Unpublished Doctoral Dissertation. Alliant International University, San Diego 2010.

Berk L. (2015). Bebekler ve Çocuklar. Doğum Öncesinden Orta Çocukluğa. Çev. N. Işıkoğlu-Erdoğan. Ankara 2015.

Bowlby J. (1969). Attachment: Attachment and Loss Series. Vol. 1. New York 1969.

Braungart J. (1994). “Genetic Influence on 'Environmental' Measurers”. Eds. J. C. DeFries, R. Plomin \& D. W. Fulker, Nature and Nurture During Middle Childhood (1994). Cambridge.

Brennan K. A., Clark C. L., \& Shaver P. R. (1998). "Self-Report Measurement of Adult Attachment: An Integrative Overview". Eds. J. A. Simpson \& W. S. Rholes, Attachment Theory and Close Relationships (1998) 46-76. New York.

Brodzinsky D. M. (1993). “Long-term Outcomes in Adoption”. The Future of Children 3 (1993) 153-166. Doi:10.2307/1602410

Brodzinsky D. M. (2011). “Children's Understanding of Adoption: Developmental and Clinical Implications”. Professional Psychology: Research and Practice 42 (2011) 200-207. 
Budak S. (2003). Psikoloji Sözlüğü. Ankara 2003.

Bukatko D. \& Daehler M.W. (2004). Child Development: A Thematic Approach. Boston $2004^{2}$.

Carnes-Holt K. \& Bratton S. C. (2014). “The Efficacy of Child Parent Relationship Therapy for Adopted Children with Attachment Disruptions”. Journal of Counseling \& Development 92/3 (2014) 328-337. Doi:10.1002/j.1556-6676.2014.00160.x.

Chao R. (1994). "Beyond Parental Control and Authoritarian Parenting Style: Understanding Chinese Parenting Through the Cultural Notion of Training”. Child Development 65 (1994) 1111-1119.

Chisholm K. (1998). “A Three Year Follow-Up of Attachment and Indiscriminate Friendliness in Children Adopted From Romanian Orphanages”. Child Development 69 (1998) 1092-1106.

Chisholm K., Carter M. C., Ames E. W. \& Morison S. J. (1995). “Attachment Security and Indiscriminately Friendly Behavior in Children Adopted from Romanian Orphanages.” Development and Psychopathology 7/2 (1995) 283-294. Doi:10.1017/S0954579400006507

Cummings E. M., Braungart-Rieker J. M. \& Rocher-Schudlich T. D. (2003). "Emotion and Personality Development in Childhood”. Eds. R. M. Lerner, M. A. Easterbrooks \& J. Mistry, Handbook of Psychology: Developmental Psychology (2003) 211-239. Hoboken.

Çocuk Hizmetleri Genel Müdürlüğü (2019). T.C. Aile, Çalışma ve Sosyal Hizmetler Bakanlığı Çocuk Hizmetleri Genel Müdürlüğü. 01.03.2019 tarihinde https://cocukhizmetleri.aile.gov.tr/evlat-edinme.

Çuhadaroğlu-Çetin F. (2001). "Kendilik Patolojisi Belirtisi Olarak Kimlik Kargaşası". Türk Psikiyatri Dergisi 12/4 (2001) 309-314.

Davidson S. \& Ireland C.A. (2009). "Substance Misuse: The Relationship Between Attachment Styles, Personality Traits and Coping in Drug and Non-Drug Users”. Drugs and Alcohol Today 9/3 (2009) 22-27.

Davies D. (2011). Child Development: A Practitioner's Guide. New York 2011.

Drozd F., Bergsund H. B., Hammerstrøm K. T., Hansen M. B. \& Jacobsen H. (2018). “A Systematic Review of Courses, Training, and Interventions for Adoptive Parents”. Journal of Child and Family Studies 27/2 (2018) 339-354. Doi: 10.1007/s10826-017-0901-7

Edens J. F. \& Cavell T. A. (1999). “A Review and Reformulation of Adoptive Relationships from an Attachment Perspective”. Adoption Quarterly 3 (1999) 43-70.

Egeland B. \& Carlson E. A. (2004). "Attachment and Psychopathology”. Eds. L. Atkinson \& S. Goldberg, Attachment Issues in Psychopathology and Intervention (2004) 27-48. Mahwah.

Engler B. (2013). Personality Theories. Belmont 20139.

Feeney J. A., Passmore N. L. \& Peterson C. C. (2007). “Adoption, Attachment, and Relationship Concerns: A Study of Adult Adoptees”. Personal Relationships 14/1 (2007) 129-147. Doi:10.1111/j.1475-6811.2006.00145.x

Feist J. \& Feist G. J. (2008). Theories of Personality. Boston $2008^{7}$.

Feldman R. S. (2017). Development Across the Life Span. UK $2017^{8}$.

Foli K. J., Lim E. \& South S. C. (2017). “Longitudinal Analyses of Adoptive Parents' Expectations and Depressive Symptoms”. Research in Nursing and Health 40/6 (2017) 564-574. Doi: 10.1002/nur.21838

Friedlander M. L. (1999). "Ethnic Identity Development of Internationally Adopted Children and Adolescents: Implications for Family Therapists”. Journal of Marital and Family Therapy 25 (1999) 43-60. Doi:10.1111/j.1752- 0606.1999.tb01109.x

Gillath O. \& Karantzas G. (2015). "Insights into the Formation of Attachment Bonds from a Social Network Perspective”. Eds. V. Zayas \& C. Hazan, Bases of Adult Attachment (2015) 131-156. New York.

Glover M. B., Mullineaux P. Y., Deater-Deckard K. \& Petrill S. A. (2010). "Parents’ Feelings Towards Their Adoptive and Non-Adoptive Children”. Infant and Child Development 19/3 (2010) 238-251.

Grossmann K., Grossmann K. E., Spangler G., Suess G. \& Unzner L. (1985). "Maternal Sensitivity and Newborns’ Orientation Responses as Related to Quality of Attachment in Northern Germany”. Eds. I. Bretherton \& E. Waters, Monographs of the Society for Research in Child Development 50 (1-2, Serial No. 209). Growing Points of Attachment Theory and Research (1985) 233-256.

Güngör D. \& Bornstein M. H. (2010). “Culture-General and Specific Associations of Attachment Avoidance and Anxiety with Perceived Parental Warmth and Psychological Control Among Turk and Belgian Adolescents”. Journal of Adolescence 33 (2010) 593-602.

Güngör D. (2008). “The Meaning of Parental Control in Migrant, Sending and Host Communities”. 
Applied Psychology: An International Review 57/3 (2008) 397-416.

Hazan C. \& Shaver P. R. (1990). "Love and Work: An Attachment-Theoretical Perspective”. Journal of Personality and Social Psychology 59/2 (1990) 270-280. Doi: 10.1037/0022-3514.59.2.270

Henderson A. J. Z., Bartholomew K., Trinke S. J., \& Kwong M. J. (2005). "When loving Means Hurting: An Exploration of Attachment and Intimate Abuse in a Community Sample”. Journal of Family Violence 20 (2005) 219-230

Hodges J., Steele M., Hillman S., Henderson K. \& Kaniuk J. (2005). “Change and Continuity in Mental Representations of Attachment After Adoption”. Eds. D. M. Brodzinsky \& J. Palacios, Psychological Issues in Adoption: Research and Practice (2005) 93-116. Westport.

Hortaçsu N. (1997). Insan İlişkileri. Ankara 1997.

Irhammar I. \& Bengtsson H. (2004). “Attachment in a Group of Adult International Adoptees”. Adoption Quarterly 8/2 (2004) 1-26. Doi:10.1300/J145v08n02_01.

Jones C. ( 2016) “Openness in Adoption: Challenging the Narrative of Historical Progress”. Child \& Family Social Work 21 (2016) 85-93. Doi: 10.1111/cfs.12113.

Judge S. (2004). “Adoptive Families: The Effects of Early Relational Deprivation in Children Adopted From Eastern European Orphanages”. Journal of Family Nursing 10 (2004) 338-356.

Juffer F. \& van IJzendoorn M. H. (2007). “Adoptees Do Not Lack Self-Esteem: A Meta-Analysis of Studies on Self-Esteem of Transracial, International, and Domestic Adoptees”. Psychological Bulletin 133 (2007) 1067-1083. Doi:10.1037/0033- 2909.133.6.1067

Juffer F., Bakermans-Kranenburg M. J. \& van IJzendoorn M. H. (2005). “The Importance of Parenting in the Development of Disorganized Attachment: Evidence from a Preventive Intervention Study in Adoptive Families”. Journal of Child Psychology and Psychiatry 46 (2005) 263-274.

Juffer F., Hoksbergen R. A. C., Riksen-Walraven J. M. A. \& Kohnstamm G. A. (1997). “Early Intervention in Adoptive Families: Supporting Maternal Sensitive Responsiveness, Infant-Mother Attachment, and Infant Competence”. Journal of Child Psychology and Psychiatry 38(1997) 1039-1050.

Juffer F., van IJzendoorn M. H. \& Bakermans-Kranenburg M. J. (2007). "Supporting Adoptive Families with Video-Feedback Intervention”. Eds. F. Juffer, M. J. Bakermans-Kranenburg \& M. H. van IJzendoorn, Promoting Positive Parenting: An Attachment Based Intervention (2007) 139-153. New York.

Kağıtçıbaşı Ç. (1970). "Social Norms and Authoritarianism: A Turkish-American Comparison”. Journal of Personality and Social Psychology 16/39 (1970) 444-451.

Kağıtçıbaşı Ç. (2007). Family, Self, and Human Development: Theory and Application. Mahwah 2007.

Kohut H. (1971). The Analysis of the Self. Madison 1971.

Krull D. S. (2014). Introduction to Psychology. Charlotte 2014.

Küçükturan A. G. \& Keleş S. (2017). “Sosyal Duygusal Gelişim”. Ed. A. Köksal-Akyol, Erken Çocukluk Döneminde Gelişim I (2017). Ankara.

Levine L. E. \& Munsch J. (2011). Child Development: An Active Learning Approach. Thousand Oaks 2011.

Levy T. \& Orlans M. (2000). “Attachment Disorder and the Adoptive Family”. Ed. T. Orlans, Handbook of Attachment Interventions (2000). New York.

Levy-Shiff R. (2001). "Psychological Adjustment of Adoptees in Adulthood: Family Environment and Adoption-Related Correlates”. International Journal of Behavioral Development 25 (2001) 97-104.

Lieberman A. F. (2003). "The Treatment of Attachment Disorder in Infancy and Early Childhood: Reflections from Clinical Intervention with Later-Adopted Foster Care Children”. Attachment \& Human Development 5/3(2003) 279-282. Doi: 10.1080/14616730310001596133

Lionetti F., Pastore M. \& Barone L. (2015). "Parenting Stress: The Roles of Attachment States of Mind and Parenting Alliance in the Context of Adoption”. Parenting: Science and Practice 15/2 (2015) 7591. Doi:10.1080/15295192.2015.1020142

Lyons-Ruth K., Connell D. B., \& Grunebaum H. U. (1990). "Infants at Social Risk: Maternal Depression and Family Support Services as Mediators of Infant Development and Security of Attachment”. Child Development 61 (1990) 85-98.

Main M. \& Solomon J. (1990). "Procedures for Identifying Infants as Disorganized/Disoriented During the Ainsworth Strange Situation”. Eds. M. T. Greenberg, D. Cicchetti \& E. M. Cummings, Attachment in the Preschool Years (1990) 121-160. Chicago.

Mainemer H., Gilman L. C. \& Ames E. W. (1998). "Parenting Stress in Families Adopting Children from Romanian Orphanages”. Journal of Family Issues 19 (1998) 164-180. 
Marcovitch S., Goldberg S., Gold A., Washington J., Wasson C., Krekewich K. \& et al. (1997). "Determinants of Behavioral Problems in Romanian Children Adopted in Ontario". International Journal of Behavioral Development 20 (1997) 17-32.

McCartney K. \& O’Connor E. (2006). “Psychosocial Development: Attachment in Young Children”. Eds. K. M Thies \& J. Travers, Handbook of Human Development for Health Care Professionals (2006) 95-112. Sudbury.

Morton N. \& Browne K. D. (1998). “Theory and Observation of Attachment and its Relationship to Child Maltreatment: A Review”. Child Abuse and Neglect 22 (1998) 1093-1105.

Newman B. M. \& Newman P. R. (2012). Development Through Life: A Psychosocial Approach. Belmont 2012.

Nickman S. L., Rosenfeld A. A., Fine P., MacIntyre J. C., Pilowsky D. J., Howe R., Derdeyn A., Bonoan Gonzales M., Forsythe L. \& Sveda S. A. (2005). "Children in Adoptive Families: Overview and Update”. Journal of the American Academy of Child and Adolescent Psychiatry 44 (2005) 987-995.

O’Connor T. G., Bredenkamp D., Rutter M. \& the English and Romanian Adoptees (ERA) Study Team (1999). “Attachment Disturbances and Disorders in Children Exposed to Early Severe Deprivation”. Infant Mental Health Journal (Special Issue: Disturbances and Disorders of Attachment) 20 (1999) 10- 29.

Palacios J. \& Brodzinsky D. (2010). “Adoption Research: Trends, Topics, and Outcomes”. International Journal of Behavioral Development 34 (2010) 270 -284.

Pearce C. A. (2009). A Short Introduction to Attachment and Attachment Disorder. London 2009.

Remkus J. (1991). “Repeated Foster Placements and Attachment Failure: Case of Joseph, Age 3”. Ed. N. Webb, Play Therapy with Children in Crisis: A Casebook for Practitioners (1991). New York.

Rothbaum F., Weisz J., Pott M., Miyake K. \& Morelli G. (2000). “Attachment and Culture”. The American Psychologist 55 (2000) 1093-1104.

Roth-Hanania R. \& Davidov M. (2004). “Attachment”. Ed. C. D. Spielberger, Encyclopedia of Applied Psychology (2004) 191-202. Amsterdam.

Rudy D. \& Grusec J. E. (2001). "Correlates of Authoritarian Parenting in Individualist and Collectivist Cultures and Implications for Understanding the Transmission of Values”. Journal of Cross-Cultural Psychology 32 (2001) 202-212.

Rushton A. (2004). “A Scoping and Scanning Review of Research on the Adoption of Children Placed from Public Care”. Clinical Child Psychology and Psychiatry 9/1 (2004) 89-106. Doi: $10.1177 / 1359104504039768$

San-Bayhan P. \& Artan İ. (2011). Çocuk Gelişimi ve Eğitimi. İstanbul 2011.

Schimmenti A., Passanisi A., Pace U., Manzella S., di Carlo G. \& Caretti V. (2014). "The Relationship Between Attachment and Psychopathy: A Study with a Sample of Violent Offenders”. Current Psychology 33 (2014) 256-270.

Schoenmaker C., Juffer F., van IJzendoorn M. H., Linting M., van der Voort A. \& BakermansKranenburg M. J. (2015). "From Maternal Sensitivity in Infancy to Adult Attachment Representations: A Longitudinal Adoption Study with Secure Base Scripts”. Attachment \& Human Development 17/3 (2015) 241-256. Doi: 10.1080/14616734.2015.1037315

Shafffer D. \& Kipp K. (2007). Developmental Psychology: Childhood \& Adolescence. Belmont $2007^{7}$.

Shek D. T. L. (1998). “A Longitudinal Study of the Relations of Family Functioning to Adolescent Psychological Well-Being”. Journal of Youth Studies 1 (1998) 195-209.

Shuk-Ching C. (2006). A Case Control Study of Attachment Style in Deliberate Self Harm Patients: A Systemic Perspective. Unpublished Doctoral Dissertation. University of Hong Kong, Hong Kong 2006.

Sigelman C. K. \& Rider E. A. (2017). Human Development Across the Life Span. Canada $2017^{9}$.

Soysal A. Ş., Bodur Ş., İşeri E. \& Şenol S. (2005). "Bebeklik Dönemindeki Bağlanma Sürecine Genel Bir Bakış”. Klinik Psikiyatri Dergisi 8/2 (2005) 88-99.

Soysal A. Ş., Özçelik A., Arhan E., İşeri E. \& Gücüyener K. (2009). “Bir Olgu Sunumu Eşliğinde Tepkisel Bağlanma Bozukluğunun Gözden Geçirilmesi”. Türkiye Klinikleri Pediatri Dergisi 18 (2009) 248-252.

Sümer N. (2006). "Yetişkin Bağlanma Ölçeklerinin Kategoriler ve Boyutlar Düzeyinde Karşılaştırılması". Türk Psikoloji Dergisi 21 (2006) 1-22.

Taylor C. (2010). A Practical Guide to Caring for Children and Teenagers with Attachment Difficulties. London 2010. 
Thompson R. A., Easterbrooks M. A. \& Padilla-Walker L. M. (2003). "Social and Emotional Development in Infancy”. Eds. R. M. Lerner, M. A. Easterbrooks \& J. Mistry, Handbook of Psychology: Developmental Psychology (2003) 91-112. Hoboken.

Tieman W., van der Ende J. \& Verhulst F. C. (2005). "Psychiatric Disorders in Young Adult Intercountry Adoptees: An Epidemiological Study”. American Journal of Psychiatry 162 (2005) 592-598.

Trawick-Smith J. (2014). Erken Çocukluk Döneminde Gelişim (Çok Kültürlü Bakış Açısı). Çev. Ed. B. Akman. Ankara 2014.

True M., Pisani L. \& Oumar F. (2001). "Infant-Mother Attachment among the Dogon in Mali”. Child Development 75/5 (2001) 1451-1466.

van den Boom D. C. (1994). "The Influence of Temperament and Mothering on Attachment and Exploration: An Experimental Manipulation of Sensitive Responsiveness among Lower-Class Mothers with Irritable Infants”. Child Development 65 (1994) 1457-1477.

van den Dries L., Juffer F., van IJzendoorn M. H. \& Bakermans-Kranenburg M. J. (2009). "Fostering Security? A Meta-Analysis of Attachment in Adopted Children”. Children Youth Services Review 31/3 (2009) 410-421.

van IJzendoorn M. H., Juffer F. \& Poelhuis C. W. K. (2005). “Adoption and Cognitive Development: A Meta-Analytic Comparison of Adopted and Nonadopted Children's IQ and School Performance”. Psychological Bulletin 131/2 (2005) 301-316. Doi: 10.1037/0033-2909.131.2.301

van Rosmalen L., van IJzendoorn M. H. \&Bakermans-Kranenburg M. J. (2014). “ABC + D of Attachment Theory: The Strange Situation Procedure as the Gold Standard of Attachment Assessments”. Eds. P. Holmes \& S. Farnfield, The Routledge Handbook of Attachment: Theory (2014). New York.

Vorria P., Papaligoura Z., Dunn J., van IJzendoorn M. H., Steele H., Kontopoulou A. \& Sarafidou Y. (2003). "Early Experiences and Attachment Relationships of Greek Infants Raised in Residential Group Care”. Journal of Child Psychology and Psychiatry and Allied Disciplines 44 (2003) 12081220.

Wassall S. (2011). Evaluation of an Attachment Theory Based Parenting Programme for Adoptive Parents and Foster Carers. Unpublished Doctoral Dissertation. University of Birmingham, Birmingham 2011.

Wilmshurst L. (2009). Abnormal Child Psychology: A Developmental Perspective. New York 2009.

Wright J., Briggs S. \& Behringer J. (2005). “Attachment and the Body in Suicidal Adolescents: A Pilot Study”. Clinical Child Psychology \& Psychiatry 10/4 (2005) 477-491.

Zeanah C. H. (2000). "Disturbances of Attachment in Young Children Adopted from Institutions". Journal of Developmental \& Behavioral Pediatrics 21 (2000) 230-236. 